\title{
PSYCHOLOGICAL RESILIENCE OF TOURISM EMPLOYEES: THE CASE OF ANTALYA*
}

\section{TURIZM PERSONELININ PSIKKOLOJIK DAYANIKLILIĞI: ANTALYA ÖRNEĞİ}

\author{
Esin YÜCEL ${ }^{1}$, Emre Ozan AKSÖZ², Birgül AYDIN
}

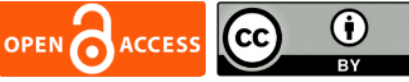

1. Öğr. Gör. Dr., Akdeniz Üniversitesi,

esinyucel@akdeniz.edu.tr, https://orcid.org/0000-0003-1371-8911

2. Doç. Dr., Anadolu Üniversitesi, Turizm Fakültesi, Turizm İşletmeciliği Bölümü, ozana@anadolu.edu.tr, https://orcid.org/0000-0002-4109-8847

3. Dr. Öğr. Üyesi, Doğuş Üniversitesi, Sanat ve

Tasarım Fakültesi, Gastronomi ve Mutfak

Sanatları, baydin@dogus.edu.tr,

https://orcid.org/0000-0003-3459-2385

Makale Türü

Araştırma Makalesi

Bașvuru Tarihi

04.08.2021

Yayına Kabul Tarihi

20.09.2021

Admission Date

09.20.2021

DOI

https://doi.org/10.30798/makuiibf.978588

* This study is an expanded and updated version

of the oral presentation presented at the 20th

National Tourism Congress on 16-19 October 2019.

\section{Abstract}

Psychological resilience is the state of being able to exhibit the demanded/expected positive behaviour when the individual is faced with difficulties. In the tourism sector where intensive labour is involved, the psychological resilience of the employees who provide the service directly to the customer against the intensive working conditions remains crucial. The aim of this study is to determine whether psychological resilience levels of accommodation employees differ according to demographic characteristics and job characteristics. The population of the research consists of the employees of five-star hotel businesses in Antalya. In the research, two-part questionnaire was used to determine the individual characteristics of the employees and psychological resilience scale for adults (PRSA). For the evaluations made on 570 questionnaires, percentage and frequency analysis, $\mathrm{t}$ test, Anova tests were applied. As a result of the analysis, it was concluded that perceptions of marital status, sector experience, status, education level and income level were determinant on psychological resilience levels of employees.

Keywords: Tourism, Psychology, Psychological Resilience, Antalya.

Öz

Psikolojik dayanıklılık, bireyin yașadığı zorluklar karșısında istenilen/beklenen olumlu davranışı sergileyebilmesi durumudur. Emek yoğun sektör olan turizm sektöründe hizmeti müşteriye doğrudan sunan çalışanların yoğun çalışma şartları karşısındaki psikolojik dayanıklılıkları önemlidir. Bu araștırmanın amacı konaklama işletmesi çalışanlarının psikolojik dayanıklılık düzeylerinin demografik özelliklere ve iş özelliklerine göre farklılık gösterip göstermediğini ortaya koymaktır. Araştırmanın evrenini Antalya faaliyet gösteren beş yıldızlı otel işletmelerinin çalışanları oluşturmaktadır. Araştırmada, çalı̧̧anların bireysel özelliklerini belirlemeye yönelik sorular ile yetişkinler için psikolojik dayanıklılık ölçeği (YPDÖ) olmak üzere iki bölümden oluşan anket formu kullanılmıştır. 570 anket üzerinden yapılan değerlendirmeler için SPSS 22.00 programında yüzde ve frekans analizi, $t$ testi, Anova testlerinden faydalanılmıştır. Yapılan analizler sonucunda medeni durum, sektör tecrübesi, statü, eğitim seviyesi ve gelir düzeyi algılarının çalışanların psikolojik dayanıklılık düzeyleri üzerinde belirleyici olduğu sonucuna ulaşılmıştır.

Anahtar Kelimeler: Turizm, Psikoloji, Psikolojik Dayaniklilk, Antalya. 


\section{Çalışmanın Amacı}

\section{GENIŞLETILMIŞ ÖZET}

Psikolojik dayanıklılık ve örgüt çıktıları arasındaki ilişkiler pek çok araştırmaya konu olmaktadır. Psikolojik dayanıklılığın çalışanlar ve örgütsel davranış değişkenleri üzerindeki önemli etkilerine işaret eden bu çalışmalar psikolojik dayanıklılık konusunu anlaşılmaya ve üzerinde çalışılmaya değer kılmaktadır. Bu bağlamda ilgili yazından yola çıkılarak turizm çalışanlarının sahip olduğu bireysel özelliklerin ve iş özelliklerinin psikolojik dayanıklılık düzeyleri üzerinde etkili olup olmadığını belirlemek amacıyla bir alan çalışması yapılmıştır.

\section{Araştırma Soruları}

Araştırmanın temel sorusu; konaklama işletmesi çalışanlarının psikolojik dayanıklılık düzeylerinin demografik değişkenlere ve işin niteliklerine göre farklılık gösterip göstermediğidir.

\section{Literatür Araştırması}

Küreselleşme ve yoğun rekabet şartlarında, benzer ürün ve hizmet sunan işletmelerin farklılaşması sahip oldukları entelektüel sermayeye bağlı hale gelmiştir. Özellikle emek yoğun sektör olan turizm sektöründe hizmeti müşteriye doğrudan sunan çalışanlar, işletme açısından rekabet üstünlüğü sağlayacak olan baş aktörlerdir. Sunulan hizmetin kalitesi ve bunun sürdürülebilirliği, müşteri memnuniyeti ve sadakati, müşteriyle birebir iletişim halinde olan işgörenlerin sahip oldukları donanıma bağlıdır. Fark yaratmak adına ön plana çıkan insan faktörünün yaşadığı zorluklar karşısında istenilen/beklenen olumlu davranışı sergileyebilmesi durumu şeklinde tanımlanabilecek psikolojik dayanıklılık kavramı tam da bu noktada önem kazanmaktadır. Günümüz örgütleri, rekabete dayalı çalışma ortamında görev tanımlarında bulunmayan fakat kurum başarısını arttıracak farklılıkları ortaya çıkaran yaratıcı ve ayrıca zorluklarla baş edecek çalışanlar istemektedirler. Çalışanlarından belirlenmiş rol tanımlarının üzerinde davranışlar bekleyen örgütlerin başında turizm işletmeleri gelmektedir. Hizmetin 7/24 devam ettiği işletmelerde sektöre ait uzun çalışma saatleri, görece düşük ücretler, gece ve hafta sonunda çalışma, işin yoğunlaştığı zamanların getirdiği baskı gibi hoşa gitmeyen çalışma koşullarının (Mısırl1, 2002) varlığı ve kaliteli hizmet verme zorunluluğu düşünüldüğünde sektör çalışanlarının zorluk ve baskı altında çalıştıklarını söylemek yanlış olmayacaktır. Özellikle sezon yoğunluğunun olduğu yaz aylarında tatil yerlerinde faaliyet gösteren işletmelerin kaliteli hizmet ve rekabet kaygıları iş görenlere de yansımakta, çalışanlardan zorluklar ve stresle mücadele etmeleri, şartlara uyum sağlamaları beklenmektedir. Psikolojik dayanıklılık, son yıllarda insanların olumlu ve güçlü yanlarına odaklanarak bu yönlerinin geliştirilmesiyle nasıl daha mutlu, verimli ve iyi bir şekilde yaşayabilecekleri üzerinde duran pozitif psikoloji bakış açısının örgütsel yansıması olan pozitif psikolojik sermayenin alt dinamiklerinden biridir (Luthans ve Youssef, 2004). Turizm sektöründe çalışan davranışlarının ve bu davranışlarda etkisi olan faktörlerin anlaşılması insan kaynağının verimli yönetimi ve hizmet kalitesinin sağlanması açısından oldukça önemlidir (Koç ve Kızanlıklı, 2017). Bu 
çalışmada konaklama işletmesi çalışanlarının psikolojik dayanıklılık düzeylerinin demografik özelliklere ve iş özelliklerine göre farklılık gösterip göstermediği üzerinde durulmuştur.

\section{Yöntem}

Araştırma evrenini Antalya'da faaliyet gösteren beş yıldızlı otellerdeki çalışanlar oluşturmaktadır. Evrenin tam sayısına ulaşmak mümkün olmadığı için erişilebilir katılımcılardan veriler derlenmiş̧tir. Bu kapsamda, tesadüfi örnekleme yönteminden yararlanılmıştır. Araştırmaya katılmayı kabul eden 15 otelin çeşitli departmanlarında çalışanlara araştırmacılar tarafından ulaşılmış ve çalışmanın amacı anlatıldıktan sonra araştırmaya katılmak isteyenlere anketler verilmiştir. 600 çalışana anket uygulanmış ve 30 tanesi çeşitli nedenlerle değerlendirme dışında tutularak 570 anket formu analizlere dâhil edilmiştir. Veriler, 1 Haziran ve 30 Temmuz 2019 tarihleri arasında toplanmıştır. Araştırma verileri için birinci bölümünde katılımcıların bireysel özelliklerini belirlemeye yönelik soruların bulunduğu anket formu kullanılmıştır. İkinci bölümde Yetişkinler için Psikolojik Dayanıklılık Ölçeği (YPDÖ) yer almaktadır. Friborg ve ark. (2005) tarafından geliştirilen YPDÖ, Basım ve Çetin (2011) tarafından Türkçe'ye uyarlanarak geçerlilik güvenirlik çalışması yapılmıştır. 33 maddeden oluşan ölçekten alınan puanlar arttıkça psikolojik dayanıklılık düzeyi artmaktadır. Verilerin analizinde SPSS 22.0 (Statistical Package for Social Sciences) paket programından faydalanılmıştır. Ankette yer alan soruların frekans dağılımları ve yüzdeleri ile standart sapma ve aritmetik ortalama değerleri hesaplanarak sonuçlar tablolar halinde gösterilmiştir. Katılımcıların bireysel özelliklerinin ve iş özelliklerinin psikolojik dayanıklılık seviyeleri üzerinde belirleyici olup olmadığını tespit edebilmek için bağımsız örneklem t-testi ve Anova testi uygulanmıştır. Yetişkinler için Psikolojik Dayanıklılık Ölçeğinin güvenilirliği Cronbach Alpha ( $\alpha$ ) katsayısı ile sınanmıştır.

\section{Sonuç ve Değerlendirme}

Katılımcıların bireysel özelliklerinin ve iş özelliklerinin psikolojik dayanıklılık düzeyleri üzerinde belirleyici olup olmadığını tespit etmeye yönelik yapılan analizler neticesinde psikolojik dayanıklılık düzeyleri deneyimlerine, statülerine, gelir düzeyi algılarına, medeni hal ve eğitim durumlarına göre farklılık göstermektedir. Evli katılımcıların psikolojik dayanıklılık düzeyleri bekâr katılımcılara göre daha yüksektir. Bunun evli katılımcıların sorumluluklarının bekâr olanlara göre daha fazla olmasından kaynaklandığı söylenebilir. Bir diğer sonuç eğitim düzeyinin, kıdemin ve gelir düzeyi algısının arttıkça psikolojik dayanıklılık seviyesinin de yükselmesidir. Eğitimin ve sektörde edinilen tecrübenin bireylerin psikolojik olarak sıkıntılara dayanmaları yönünde pozitif etkisinden söz etmek mümkündür. Ayrıca maddi kazançlarına ilişkin algılarında gelir düzeyleri arttıkça bireylerin psikolojik olarak sıkıntılara dayanma dirençleri de artmaktadır. Erkek ve genç katılımcıların psikolojik dayanıklılıklarının kadın ve ileri yaş katılımcılara göre daha yüksek olduğu, yaş, cinsiyet ve departman değişkenlerine göre ise bir farklılık olmadığı tespit edilmiştir. Turizm işletmelerinin birbirine benzer hizmet ve ürün sunduğu piyasa şartlarında, farkl1lığı ve müşteri memnuniyetini sağlayacak olan, hizmeti birebir müşteriye sunan insan kaynağıdır. Bu açıdan standart hizmetleri fark yaratacak şekilde sunacak 
olan beşeri sermayenin zorluklar karşısında göstereceği dayanıklılık düzeyi konaklama işletmeleri açısından önemlidir. Eğitimli ve deneyimli çalışanlarda dayanıklılık düzeyinin daha fazla olması bu durumun geliştirilebilir olduğunu göstermektedir. Dolayısıyla işletmeler bu konuda çalışanlarına destek sağlayabilir. Ayrıca gelir düzeyindeki farklılıkların psikolojik dayanıklılık üzerinde etkili olması çalışanların dayanıklılığının maddi kazanımlarla artırılabileceği anlamına gelebilir. Turizm sektörü vardiyalı çalışma sistemini ve özellikle sezonda fazla ve düzensiz çalışmayı içeren özelliğe sahiptir. Bu açıdan turizm çalışanlarının mesai düzeni ile çalışanlarına göre daha fazla fiziksel ve ruhsal risk yaşadıkları, dayanıklı olmaya ihtiyaçlarının diğerlerine göre daha fazla olduğu söylenebilir. Dolayısıyla turizm yöneticileri, turizm sektörünün kendine has özelliklerini göz önüne alarak çalışma ortamının fiziksel veya psikolojik olarak zorlayıcı olduğunu kabullenmeli ve insan kaynakları prosedürlerini dikkatli şekilde uygulamalıdırlar. Örneğin çalışanların psikolojik olarak ne durumda olduklarının gözetilmesi, çalışanların dayanıklılık düzeylerinin düzenli olarak ölçülmesi ve eğer gerekiyorsa ücretli, ücretsiz veya hastalık izni prosedürlerinin yeniden gözden geçirilmesi gerekebilir. Çalışanların izin durumları ve haftalık çalışma saatleri titizlikle ayarlanıp, çalışanlar dinlenme ve stresle baş etme teknikleri konusunda desteklenebilir. Ayrıca personel için sorunlarını paylaşabilecekleri açık iletișim ortamı oluşturulması hizmet kalitesini, müşteri memnuniyetini, müşteri sadakatini ve daha pek çok örgütsel çıktıyı etkileyecektir. 


\section{INTRODUCTION}

Under the conditions of globalization and intense competition, the differentiation of enterprises offering similar products and services became dependent on their intellectual capital. Particularly in the labour-intensive tourism sector, the employees who directly provide service to the customers are the main actors to provide competitive advantage for the enterprise. The quality of the service and its sustainability, as well as the customer satisfaction and loyalty, depend on the equipment of the employees who are in direct communication with the customer. The concept of psychological resilience, which can be defined as the human factor that stands out in order to make a difference by exhibiting the demanded/expected positive behaviour in the face of the difficulties experienced, gains importance at this point.

Today, organizations demand employees who can deal with challenges in a competitive working environment while being creative enough to reveal the differences which may increase the corporate success although they are not included in their job description. Tourism enterprises are the leading organizations that demand behaviours beyond the defined role descriptions from their employees. Considering the presence of compelling working conditions such as industry-specific long working hours, relatively low wages, working at night and weekends, the increasing pressure during the busy times (Misirl1, 2002), as well as the obligation to provide quality service in businesses where the service continues 24/7, it is agreeable to say that sector employees work under pressure and expose to difficulties. Particularly during high season, the concerns related to quality service and competition in tourism enterprises inevitably affect those who work in the businesses, and employees are expected to cope with difficulties and stress, and adapt to the conditions. This situation raises the concept of psychological resilience of the employees who work in tourism as a labour-intensive sector.

The relationship between psychological resilience and organizational outcomes has been the subject of many studies. Such studies that point out the significant impacts of psychological resilience on employees and organizational behaviour variables make psychological resilience worth understanding and studying on. Within this context, this study aims to determine whether or not individual characteristics and job characteristics of employees make an impact on psychological resilience levels. Accordingly, firstly the theoretical framework was drawn in the study, the method and analysis of the research were explained, and finally the findings were discussed in the light of the relevant literature. 


\section{THEORETICAL FRAMEWORK}

Psychological resilience is one of the sub-dynamics of positive psychological capital, which is the organizational reflection of the positive psychology perspective, emphasizing how people can live happier, more productively and well by focusing on their positive and strong sides in the recent years (Luthans and Youssef, 2004). Positive psychological capital refers to the positive-oriented human resource that is necessary for the organization to survive even under adverse conditions (Keleş, 2011). The basic dynamics of the positive psychological capital concept, which includes being essentially positive and goes beyond the intellectual capital of organizations in order to gain competitive advantage, are self-efficacy, optimism, hope and resilience (Figure 1).

Figure 1. Positive Psychological Capital and Sub-Dimensions

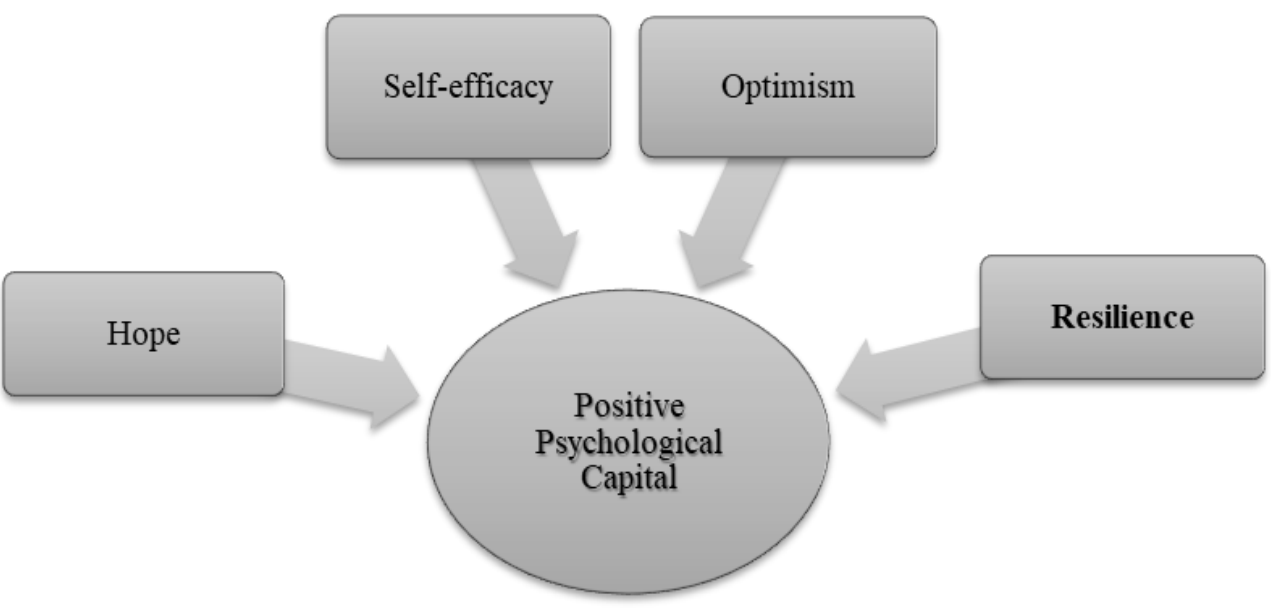

Given the use of the concept, which is the subject of the study and used as "resilience" or "hardness" in the international literature, it is seen that in national literature it has been translated and used in different ways such as indomitableness, psychological strength, self-recovery power, psychological resilience. The concept to be used as "resilience" in this study is the state of being able to display the desired/expected positive behaviour when the individual is faced with difficulties. Psychological resilience, which was first described by Suzanne C. Kobasa (1979) as a personality trait, is being capable of adapting and accommodating oneself to this process when faced with difficulties, trauma, disaster, and even stress factors such as family and relationship problems, serious health problems, occupational or economic difficulties (Newman, 2002). Psychological resilience can also be explained as the power of the individual to combat negative events such as disappointment, conflicts, uncertainties, and finally win the battle and recover oneself (Çetin and Basım, 2012).

Psychologically resilient people are the individuals who can adapt well despite stressful life events (Luthar and Zigler, 1991; Zautra, Hall and Murray, 2010). In order to be able to overcome problems and refer to psychological resilience which is defined as the ability to adapt well to negatively changing conditions, there must be ongoing challenges in life and positive adaptation to these challenges must be fully and adequately demonstrated (Fletcher and Sarkar, 2013). Psychological resilience may 
vary depending on time, situation and the environment. It has two separate dimensions: challenge and good adaptation (Luthar et al., 2006). An individual who has not been exposed to any compelling situation cannot be defined as psychologically resilient (Frasser et al., 1999; Luthar et al., 2000).

Psychological resilience is a definition that expresses the positive side of individuals' reactions to challenges and troubles (Rutter, 1990). The correlation of attitude, coping capacity and psychological resilience as a personal power (Joseph, 1994), which can be observed in the individuals who can adapt to the challenges of life and manage their problems well, with different variables has been the subject of many studies. In this context, the studies conducted for psychological resilience as a result of the literature review are given in Table 1.

Table 1. Researches of Psychological Resilience

\begin{tabular}{|c|c|}
\hline Author and Year & Variables Examined in Studies \\
\hline Özcan (2005) & $\begin{array}{l}\text { Psychological resilience levels of high school students and family } \\
\text { status of togetherness }\end{array}$ \\
\hline Gürgan (2006) & $\begin{array}{l}\text { The effect of indomitableness training of group counselling } \\
\text { program for university students on the resilience levels of } \\
\text { individuals }\end{array}$ \\
\hline Eminağaoğlu (2006) & $\begin{array}{l}\text { Strong friendships and emotional bonding along with the strength } \\
\text { characteristics of street children }\end{array}$ \\
\hline Karaırmak and Siviş-Çetinkaya (2011) & $\begin{array}{l}1999 \text { earthquake survivors; the relationship of psychological } \\
\text { resilience variable with self-esteem, positive emotions and focus of } \\
\text { control }\end{array}$ \\
\hline Y1lmaz and Sipahioğlu (2012) & $\begin{array}{l}\text { Psychological resilience levels of adolescents living with a single } \\
\text { parent }\end{array}$ \\
\hline Eraslan-Çapan and Arıcıoğlu (2014) & $\begin{array}{l}\text { The relationship between forgiveness and psychological resilience } \\
\text { in university students }\end{array}$ \\
\hline Çelik, Sanberk and Deveci (2017) & $\begin{array}{l}\text { Psychological resilience and hopelessness as predictors of life } \\
\text { satisfaction in teacher candidates }\end{array}$ \\
\hline Yıldırım et al. (2015) & $\begin{array}{l}\text { The relationship between psychological resilience and self- } \\
\text { construal of adolescents aged 14-18 }\end{array}$ \\
\hline Terzi (2008) & $\begin{array}{l}\text { The relationship between the psychological resilience of university } \\
\text { students and the social support they perceive }\end{array}$ \\
\hline Güloğlu and Karaırmak (2010) & $\begin{array}{l}\text { Relationship between university students, loneliness and self- } \\
\text { esteem and psychological resilience }\end{array}$ \\
\hline Yalım (2007) & $\begin{array}{l}\text { Relationship between coping ways, psychological resilience, } \\
\text { optimism and gender with first-year university students }\end{array}$ \\
\hline Terzi (2005) & $\begin{array}{l}\text { Psychological resilience model that affects their subjective well- } \\
\text { being by ensuring effective coping in stressful living situations in } \\
395 \text { university students }\end{array}$ \\
\hline Terzi (2013) & $\begin{array}{l}\text { The relationship between psychological resilience and perceived } \\
\text { social support in university students }\end{array}$ \\
\hline Malkoç and Yalçın (2015) & $\begin{array}{l}\text { Relationships between psychological resilience, social support, } \\
\text { coping with stress and psychological well-being variables in } \\
\text { university students }\end{array}$ \\
\hline Callahan (2000) & $\begin{array}{l}\text { Relationship between the patients with chronic pain problems, } \\
\text { endurance, stress and disease symptoms }\end{array}$ \\
\hline Maddi et al. (2002) & Relationship between endurance, stress, and disease symptoms \\
\hline Kobasa et al. (1982) & $\begin{array}{l}\text { Individuals with a high level of resilience and well-being in a } \\
\text { stressful environment among managers }\end{array}$ \\
\hline Kobasa (1979) & $\begin{array}{l}\text { Relationship between people who work as managers, high } \\
\text { endurance level, and physical and mental health }\end{array}$ \\
\hline
\end{tabular}




\begin{tabular}{|c|c|}
\hline Kobasa and Puccetti (1983) & Personality and social resources in terms of resistance to stress \\
\hline Ganellen and Blaney (1984) & $\begin{array}{l}\text { Level of resilience, stressful environment and social support } \\
\text { among female university students }\end{array}$ \\
\hline Funk and Houston (1987) & A critical analysis of the Hardiness Scale's validity and utility. \\
\hline Allred and Smith (1989) & Level of resilience, anxiety and depression in university students \\
\hline Rhodewalt and Zone (1989) & Adult female participants, resilience, anxiety and depression \\
\hline Li et al. (2012) & $\begin{array}{l}\text { Relationship between the adults who experienced earthquakes, } \\
\text { demographic factors and resilience }\end{array}$ \\
\hline Rossi et al. (2007) & $\begin{array}{l}\text { Psychological resilience in the relationship between stress and life } \\
\text { satisfaction after the loss of a spouse }\end{array}$ \\
\hline Gooding et al. (2012) & $\begin{array}{l}\text { Comparison of young adults under } 26 \text { and adults over } 64 \text { for } \\
\text { psychological resilience }\end{array}$ \\
\hline Bozgeyikli and Şat (2014) & $\begin{array}{l}\text { Relationship between organizational citizenship behaviours and } \\
\text { psychological resilience levels of the teachers working in private } \\
\text { schools }\end{array}$ \\
\hline Campbell-Sills et al. (2006) & $\begin{array}{l}\text { The relationship between psychological resilience, personality } \\
\text { traits, coping styles and psychiatric symptoms in university } \\
\text { students }\end{array}$ \\
\hline Voegler (2000) & $\begin{array}{l}\text { The role of child and mother factors in reducing the impact of } \\
\text { cumulative risk on the resilience of the homeless youth living in } \\
\text { shelters }\end{array}$ \\
\hline Bonanno et al. (2006) & $\begin{array}{l}2752 \text { individuals who witnessed the September } 11 \text { attacks, post- } \\
\text { traumatic psychological resilience }\end{array}$ \\
\hline Min et al. (2013) & $\begin{array}{l}\text { The relationship between psychological resilience and emotional } \\
\text { stress in cancer patients }\end{array}$ \\
\hline Bitmiş et al. (2013) & $\begin{array}{l}\text { Mediating role of organizational identification in the effect of } \\
\text { psychological resilience on burnout }\end{array}$ \\
\hline Akçay (2011) & $\begin{array}{l}\text { Positive psychological capital's effects on job satisfaction with } \\
\text { respect to personal values and a research }\end{array}$ \\
\hline Erkuş and Findıklı (2013) & $\begin{array}{l}\text { A research on the impact of psychological capital to job } \\
\text { satisfaction, job performance and intention to quit }\end{array}$ \\
\hline Şahin and Buzlu (2017) & $\begin{array}{l}\text { The mediating role of perceived stress in the relationship of } \\
\text { psychological resilience with self-efficacy, social support and } \\
\text { effective coping in nursing students }\end{array}$ \\
\hline $\begin{array}{l}\text { Prayag, Spector, Orchiston and } \\
\text { Chowdhury (2020). }\end{array}$ & $\begin{array}{l}\text { The relationship between different types of resilience } \\
\text { (psychological, employee and organizational resilience) that affect } \\
\text { the recovery of tourism organizations }\end{array}$ \\
\hline
\end{tabular}

When Table 1 is examined, it is seen that there are studies addressing the significant effects of psychological resilience on employees and organizational behavior variables. The aim of this study is to determine the relationship between the psychological resilience levels of employees in the light of theoretical knowledge on resilience; tourism employees and their demographics and job characteristics. The hypotheses created for this purpose are as follows:

$\mathrm{H}_{1}$ : Psychological resilience levels of the employees vary according to demographical variables.

$\mathrm{H}_{1 \mathrm{a}}$ : Psychological resilience levels of the employees vary according to the gender variable.

$\mathrm{H}_{1 \mathrm{~b}}$ : Psychological resilience levels of the employees vary according to the marital status variable.

$\mathrm{H}_{1 \mathrm{c}}$ : Psychological resilience levels of the employees vary according to the education variable.

$\mathrm{H}_{1 \mathrm{~d}}$ : Psychological resilience levels of the employees vary according to the age variable. 
$\mathrm{H}_{2}$ : Psychological resilience levels of the employees vary according to the job characteristics variable.

$\mathrm{H}_{2 \mathrm{a}}$ : Psychological resilience levels of the employees vary according to their experiences.

$\mathrm{H}_{2 \mathrm{~b}}$ : Psychological resilience levels of the employees vary according to the department they work.

$\mathrm{H}_{2 c}$ : Psychological resilience levels of the employees vary according to their perception of income level.

$\mathrm{H}_{2 \mathrm{~d}}$ : Psychological resilience levels of the employees vary according to their status.

\section{METHODOLOGY}

\subsection{Sampling and data collection}

The research, including the pilot study, was conducted in Antalya (Turkey) between 1 June and 30 July 2019. Antalya offers various tourism attractions for tourists with its historical and natural beauties, socio-cultural values. It is one of the most known tourism destinations in Turkey. The accessible sampling frame of the research is composed of five-star hotel employees in Antalya. As the exact number of population is unclear, the simple random method of sampling was applied in the study for selection of participants. In this context, 600 questionnaires were applied by the researcher to the employees working in 15 hotels in Antalya who accepted to participate in the study.

\subsection{Measurement}

The questionnaire used for obtaining research data is composed of two parts. In the first part are demographic questions to determine the individual characteristics of the participants. In the second part, the Psychological Resilience Scale for Adults (PRSA) developed by Friborg et al. (2005) is provided with 33 statements. The Psychological Resilience Scale for Adults (PRSA) developed by Friborg et al. (2005) was adapted to Turkish by Basim and Cetin (2011) and accordingly the validity and reliability study was conducted. The adapted version by Basim and Çetin (2011) was used in the study.

\subsection{Data Analysis}

As a result of the univariate and multivariate extreme and normal distributions observations, 30 surveys were extracted from the data set and 570 surveys were analysed. Since, the data exhibits a normal distribution independent sample t-test and Anova were performed in order to determine whether or not the individual characteristics and job characteristics are determent on their psychological resilience levels. 


\section{FINDINGS}

\subsection{Findings Regarding Demographic Characteristics of Participants}

The Cronbach Alpha $(\alpha)$ coefficient of the Psychological Resilience Scale for Adults is 0,827 . The findings regarding the demographic and job characteristics of the participants in the research are shown in Table $2.55 .1 \%$ of the participants are women while $44.9 \%$ are men. When the education status of the participants are considered, it is seen that $43.5 \%$ of them are undergraduate, $35.6 \%$ are graduated from high school, $14.9 \%$ from primary school, and $6.0 \%$ are graduates. When the age ranges are considered, $57.2 \%$ of them are $31-50 ; 28.4 \%$ are $18-30$, and $14.4 \%$ are 51 and over. When the marital status of the participants is evaluated, $67.0 \%$ of them are married, $33.0 \%$ are single. In terms of the department the participants work, housekeeping is on the first rank with $29.1 \%$, and this is followed by food and beverages services with $26.3 \%$, front desk with $20.7 \%$, security with $18.6 \%$, and animation with $5.3 \%$. When the working periods in the business are examined, $42.5 \%$ of them are less than 5 years, $48.8 \%$ are $5-10$ years, $4.2 \%$ are $11-15$ years, and $4.6 \%$ are 16 years and more. It is seen that $66.0 \%$ of the income level perceptions of the participants are medium, $22.5 \%$ are low and $11.62 \%$ are high. When the status of the participants is considered, $82.8 \%$ are staff, $14.4 \%$ are mid-level managers and $2.8 \%$ are senior managers.

Table 2. Findings Regarding Demographic Characteristics of Participants

\begin{tabular}{|c|c|c|c|}
\hline & & f & $\%$ \\
\hline \multirow{3}{*}{ Gender } & Female & 314 & 55,1 \\
\hline & Male & 256 & 44,9 \\
\hline & Total & 570 & 100,0 \\
\hline \multirow{5}{*}{ Education } & Primary School & 85 & 14,9 \\
\hline & High School & 248 & 43,5 \\
\hline & University & 203 & 35,6 \\
\hline & Graduate & 34 & 6,0 \\
\hline & Total & 570 & 100,0 \\
\hline \multirow{4}{*}{ Age Range } & $18-30$ & 162 & 28,4 \\
\hline & $31-50$ & 326 & 57,2 \\
\hline & $51+$ & 82 & 14,4 \\
\hline & Total & 570 & 100,0 \\
\hline \multirow{3}{*}{ Marital Status } & Married & 382 & 67,0 \\
\hline & Single & 188 & 33,0 \\
\hline & Total & 570 & 100,0 \\
\hline \multirow{6}{*}{ Department } & Housekeeping & 166 & 29,1 \\
\hline & Front Desk & 118 & 20,7 \\
\hline & Food and Beverages & 150 & 26,3 \\
\hline & Security & 106 & 18,6 \\
\hline & Animation & 30 & 5,3 \\
\hline & Total & 570 & 100,0 \\
\hline \multirow[t]{2}{*}{ Working Period in Business } & Less than 5 years & 242 & 42,5 \\
\hline & $5-10$ years & 278 & 48,8 \\
\hline
\end{tabular}




\begin{tabular}{|l|l|c|c|}
\hline \multirow{4}{*}{ Perception of Income Level } & $11-15$ years & 24 & 4,2 \\
\cline { 2 - 4 } & 16 years+ & 26 & 4,6 \\
\cline { 2 - 4 } & Total & 570 & 100,0 \\
\hline \multirow{4}{*}{ Status } & Low & 128 & 22,5 \\
\cline { 2 - 4 } & Medium & 376 & 66,0 \\
\cline { 2 - 4 } & High & 66 & 11,6 \\
\cline { 2 - 4 } & Total & 570 & 100,0 \\
\hline & Senior Manager & 16 & 2,8 \\
\cline { 2 - 4 } & Mid-level Manager & 82 & 14,4 \\
\cline { 2 - 4 } & Staff & 472 & 82,8 \\
\cline { 2 - 4 } & Total & 570 & 100,0 \\
\hline
\end{tabular}

\subsection{Findings on the Differences Between Participants' Individual Characteristics and}

\section{Psychological Resilience Levels}

This part of the study includes the findings regarding the analyses conducted with independent t-test and Anova test used in order to determine whether or not the individual characteristics and job characteristics are determent on their psychological resilience levels. Accordingly, the hypotheses presented in the research were tested. In this context, the findings obtained as a result of the t-test and Anova test analysis regarding the difference between the psychological resilience levels of the participants and their demographic characteristics are given in Table 3.

Table 3. T-Test and Anova Test Findings Regarding the Difference Between Psychological Resilience Levels and Demographic Characteristics of The Participants.

\begin{tabular}{|c|c|c|c|c|c|c|}
\hline \multicolumn{2}{|c|}{ Demographic Characteristics } & $\mathbf{n}$ & $\overline{\mathbf{x}}$ & s. s. & $t / F$ & $\mathbf{p}$ \\
\hline \multirow{2}{*}{ Gender } & Female & 314 & 109,88 & 21,08 & \multirow{2}{*}{1,412} & \multirow{2}{*}{0,159} \\
\hline & Male & 256 & 107,41 & 20,37 & & \\
\hline \multirow{2}{*}{ Marital status } & Married & 382 & 111,42 & 21,49 & \multirow{2}{*}{4,402} & \multirow{2}{*}{$0,001^{*}$} \\
\hline & Single & 188 & 103,39 & 18,17 & & \\
\hline \multirow{4}{*}{ Education } & Primary School & 85 & 104,12 & 18,09 & \multirow{4}{*}{10,591} & \multirow{4}{*}{$0,001 *$} \\
\hline & High School & 248 & 110,83 & 21,29 & & \\
\hline & University & 203 & 112,18 & 21,93 & & \\
\hline & Graduate & 34 & 121,88 & 22,50 & & \\
\hline \multirow{3}{*}{ Age } & $18-30$ & 162 & 108,09 & 22,76 & \multirow{3}{*}{1,530} & \multirow{3}{*}{0,217} \\
\hline & $31-50$ & 326 & 109,90 & 20,18 & & \\
\hline & 51 and over & 82 & 105,60 & 18,83 & & \\
\hline
\end{tabular}

Table 3 shows the results of the t-test for gender and marital status variables and the Anova test results for education level and age. In this context, it is seen that the psychological resilience levels of the employees show a significant difference according to the marital status and educational status factors $(\mathrm{p}<0.05)$. Married employees have higher levels of resilience than single ones. In addition, a positive and significant relationship was discovered between the education level of the employees and their psychological resilience levels. According to the finding obtained, it is possible to say that the higher is 
the level of education, the higher is the level of psychological resilience. On the other hand, psychological resilience levels did not differ significantly according to gender and age variables $(\mathrm{p}<0.05)$.

\subsection{Findings on the Differences Between the Job Characteristics and Psychological} Resilience Levels of the Research Participants

Table 4 shows the Anova test results for variables related to the job characteristics. According to the findings, the psychological resilience levels of the employees differ significantly according to their experiences, status and perceptions of income level ( $p<0.05$ ). The psychological resilience levels of the participants in the mid-level manager group are higher than other age groups. Moreover, a positive and significant relationship was found between employees' perceptions of their seniority and income level, and their psychological resilience. Based on the findings obtained, it can be concluded that the experience and income level perceptions of the employees increase in line with their psychological resilience levels.

Table 4. Anova Test Results Regarding the Differences Between Job Characteristics and Psychological Resilience Levels of The Research Participants

\begin{tabular}{|c|c|c|c|c|c|c|}
\hline \multicolumn{2}{|c|}{ Job Characteristics } & $\mathbf{n}$ & $\overline{\mathbf{x}}$ & S. S. & $\mathbf{t} / \mathbf{F}$ & $\mathbf{p}$ \\
\hline \multirow{4}{*}{ Experience } & Less than 5 & 242 & 96,58 & 20,51 & \multirow{4}{*}{4,744} & \multirow{4}{*}{$0,003 *$} \\
\hline & 5-10 years & 278 & 107,00 & 21,09 & & \\
\hline & $11-15$ years & 24 & 107,24 & 22,28 & & \\
\hline & 16 yearst & 26 & 111,32 & 22,80 & & \\
\hline \multirow{3}{*}{ Status } & Senior Manager & 16 & 108,77 & 20,78 & \multirow{3}{*}{4,595} & \multirow{3}{*}{$0,010^{*}$} \\
\hline & Mid-level Manager & 82 & 110,83 & 26,35 & & \\
\hline & Personnel & 472 & 107,93 & 19,37 & & \\
\hline \multirow{3}{*}{$\begin{array}{l}\text { Perception of } \\
\text { Income Level }\end{array}$} & Low & 128 & 104,20 & 17,72 & \multirow{3}{*}{4,163} & \multirow{3}{*}{$0,016^{*}$} \\
\hline & Medium & 376 & 108,88 & 21,02 & & \\
\hline & High & 66 & 110,31 & 23,77 & & \\
\hline \multirow{5}{*}{ Department } & Housekeeping & 166 & 105,75 & 20,02 & \multirow{5}{*}{1,916} & \multirow{5}{*}{0,116} \\
\hline & Front Desk & 118 & 108,10 & 19,06 & & \\
\hline & Food and Beverages & 150 & 110,79 & 23,99 & & \\
\hline & Security & 106 & 111,88 & 19,64 & & \\
\hline & Animation & 30 & 107,07 & 16,18 & & \\
\hline
\end{tabular}

Psychological resilience levels have shown no significant difference according to the department they work $(\mathrm{p}<0.05)$. Table 5 includes the information regarding acceptance and rejection status of hypotheses. In this scope, based on the analyses completed, $\mathrm{H}_{1 \mathrm{a}}, \mathrm{H}_{1 \mathrm{~d}}, \mathrm{H}_{2 \mathrm{~b}}$ hypotheses were rejected while $\mathrm{H}_{1 \mathrm{~b}}, \mathrm{H}_{1 \mathrm{c}}, \mathrm{H}_{2 \mathrm{a}}, \mathrm{H}_{2 \mathrm{c}}$ and $\mathrm{H}_{2 \mathrm{~d}}$ hypotheses were accepted. 
Table 5. Acceptance and Rejection Status of The Hypotheses

\begin{tabular}{|c|c|c|c|c|}
\hline & $\mathbf{a}$ & $\mathbf{b}$ & $\mathbf{c}$ & $\mathbf{d}$ \\
\hline $\mathbf{H}_{1}$ & Rejected & Accepted & Accepted & Rejected \\
\hline $\mathbf{H}_{2}$ & Accepted & Rejected & Accepted & Accepted \\
\hline
\end{tabular}

\section{CONCLUSION AND RECOMMENDATION}

In this study, it was aimed whether the psychological resilience levels of accommodation enterprise employees differ according to their demographic characteristics and job characteristics. As a result of analysis, it was concluded that psychological resilience levels of the participants vary according to their experiences, status, perceptions of income level, marital status and educational level. In this context, it is one of the findings that the level of psychological resilience of the married participants was higher than that of single participants. This result can be associated with the fact that married participants have more responsibilities than single ones. Another important finding obtained in the study is that the level of psychological resilience increases proportionally in line with the level of education, seniority and income level. This indicates the positive effect of education and experience in the sector in terms of resisting psychological problems. In addition, in parallel to the study of Li et al. (2012), it was concluded that there was an increase in direct proportion between the increase in the perception of income level and the resistance of individuals to cope with psychological problems. According to another finding of the study, male and young participants had more psychological resilience than female and older participants. According to the study, no difference was found in the psychological resilience levels of the employees according to age, gender and department variables. Based on this result, it can be said that the education level, seniority and income level are more important for the psychological resilience of the five-star hotel employees in Antalya.

\subsection{Managerial and Theoretical Implications}

It is the human resource that offers the service that will provide difference and the customer satisfaction in the market conditions where tourism enterprises offer similar services and products. In this respect, the level of resilience of human capital, which will provide standard services in a way that makes a difference, is important for the accommodation enterprises. A higher level of resilience in trained and experienced employees indicates that this situation can be improved. Therefore, businesses can provide support to their employees in this regard. In addition, the fact that differences in income level have an impact on psychological resilience is one of the findings in the study. This may indicate that the resilience of staff can be increased by financial gains. Apart from this, the necessity of implementing practices for the development and improvement of the income level of employees in tourism as a labour-intensive sector was once again revealed in this study. 
The seasonality of tourism allows working only in certain periods of the year. Additionally, it has a job character that includes shift working system and long working hours and, accordingly, irregular work during the season. In this respect, it can be said that tourism employees have more physical and mental risks than the employees in other sectors, and accordingly they need to be more resilient than others. Therefore, taking into account the peculiarities of the tourism sector, tourism managers should acknowledge that the tourism sector is physically or psychologically challenging in terms of the working environment, and applying the human resources procedures carefully becomes prominent. Accordingly, any possible problems may be avoided by monitoring employees' psychological well-being, regularly measuring employee resilience, and revising paid, unpaid or sick leave procedures. Employees' leave status and weekly working hours can be adjusted, and employees can be provided with professional support for resting and stress management techniques. In addition, creating an open communication environment where employees can share problems will affect service quality, customer satisfaction, customer loyalty and its sustainability, and many other organizational outputs.

As a result, it is thought that the results of this research will contribute to the academic and corporate knowledge about the psychological resilience of the five-star hotel employees in Antalya. The result of the research is important in terms of understanding the psychological state of the employees working in tourism sector. Thus, it will be possible to understand the importance of the human factor in tourism as a labour-intensive sector.

\subsection{Research Limitations and Future Research}

The aim of this study is to determine whether the personal characteristics and job characteristics of five-star hotel employees are effective on their psychological resilience. In this context, the evaluations and suggestions made in line with the results obtained in the study are valid within the scope of the "five-star hotel employees in Antalya", which is the sample of the research carried out.

In the study, quantitative research methods were used to examine the effect level of individual characteristics and job characteristics of employees on psychological resilience levels. While quantitative research helps the researcher to produce generalizable results and allows comparison between different groups, it has limitations such as the difficulty of taking excellent quality and number of samples and the possibility of reflecting bias in the measuring tool. In addition, psychological resilience is a concept that is hard to evaluate objectively, and it has the limitation of evaluating the individual with self-reported measurement tools. The findings of the research and the reliability of the scales used are limited to the answers given by the people in the sample group. Therefore, further researches on different sample groups may be carried out. Dealing with the concept of resilience with sample groups from different sectors may be another research topic. This will allow for a comparison between sectors. In addition, qualitative research methods may be used to examine meticulously the concept of psychological resilience of tourism employees, which includes a subjective structure. 


\section{REFERENCES}

Akçay, V. H. (2011). Pozitif psikolojik sermayenin kişisel değerler bakımından iş tatminine etkisi ve bir araștırma. (Unpublished Dissertation). İstanbul University Institute of Social Sciences, İstanbul.

Allred, K. D. and Smith, T. W. (1989). The hardy personality: cognitive and psychological responses to evaluative threat. Journal of Personality and Social Psychology, 56(2), 257-266.

Bitmiş, G.M., Sökmen, A. and Turgut, H. (2013). Psikolojik dayanıklılı̆̆ın tükenmişlik üzerine etkisi: Örgütsel özdeşleşmenin arac1lık rolü. Gazi Üniversitesi İktisadi ve İdari Bilimler Fakültesi Dergisi, 15(2), 27-40.

Bonanno, G.A., Galea, S., Bucciarelli, A. and Vlahov, D. (2006). Psychological resilience after disaster: New York City in the aftermath of the September 11th terrorist attack. Psychol Sci., 17(3), 181-186. DOI: 10.1111/j.1467-9280.2006.01682.x

Bozgeyikli, H. and Şat, A. (2014). Öğretmenlerde psikolojik dayanıklılık ve örgütsel vatandaşlık davranışlarının bazı değişkenler açısından incelenmesi: Özel okul örneği. Hak Işs Uluslararası Emek ve Toplum Dergisi, 3(5), 172 - 191.

Callahan, C. D. (2000). Stress, coping, and personality hardiness in patients with temporomandibular disorders. Rehabilitation Psychology, 45(1), 38-48. https://doi.org/10.1037/0090-5550.45.1.38

Campbell-Sills, L., Cohan, S. L. and Stein, M. B. (2006). Relationship of resilience to personality, coping and psychiatric symptpoms in young adults. Behaviour Research and Therapy, 44(4), 585-599. https://doi.org/10.1016/j.brat.2005.05.001

Çelik, M., Sanberk, İ. and Deveci, F. (2017). Öğretmen adaylarının yaşam doyumlarının yordayıcısı olarak psikolojik dayanıklılık ve umutsuzluk. İlkögretim Online, 16(2), 654654.

Çetin, F. and Basım, N. (2012). Örgütsel psikolojik sermaye: Bir ölçek uyarlama çalışması. Amme İdaresi Dergisi, 45(6), 121-137.

Eminağaoğlu, N. (2006). Güç koşullarda yaşayan sokak çocuklarında dayanıklılık. (Unpublished doctoral thesis). Ege University Institute of Social Sciences, Izmir.

Eraslan Çapan, Y. and Arıcıoğlu, Y. (2015). Forgiveness as predictor of psychological resiliency. e-Uluslararası Eğitim Araştırmaları Dergisi, 5(4), 70-82.

Erkuş, A. and Fındıklı, M.A. (2013). A research on the impact of psychological capital to job satisfaction, job performance and intention to quit. Istanbul University Journal of the School of Business, 42(2), 302-318.

Fletcher, D. and Sarkar, M. (2013). Psychological resilience: A review and critique of definitions, concepts, and theory. European Psychologist, 18(1), 12-23. https://doi.org/10.1027/1016-9040/a000124

Frasser, M. W., Richman, J.M. and Galinsky, M. J. (1999). Risk, protection, and resilience: Toward a conceptual framework for social practice. Social Work Research, 23(3), 129208. https://doi.org/10.1093/swr/23.3.131.

Friborg, O., Barlaug D., Martinussen, M., Rosenvinge, J. H. and Hjemdal, O. (2005). Resilience in Relation to Personality and Intelligence. International Journal of Methods in Psychiatric Research, 14(1), 29-42.

Funk, S. C. and Houston, B. K. (1987). A critical analysis of the Hardiness Scale's validity and utility. Journal of Personality and Social Psychology, 53(3), 572-578. https://doi.org/10.1037/0022-3514.53.3.572 
Ganellen, R. J. and Blaney, P. H. (1984). Hardiness and social support as moderators of the effects of life stress. Journal of Personality and Social Psychology, 47(1), 156-163. https://doi.org/10.1037/0022-3514.47.1.156

Gooding, P. A., Hurst, A., Johnson, J. and Tarrier, N. (2012). Psychological resilience in young and older adults. International Journal of Geriatric Psychiatry, 27(3), 262-270.

Güloğlu, B. and Karaırmak, Ö. (2010). Üniversite öğrencilerinde yalnızlığın yordayıcısı olarak benlik saygısı ve psikolojik sağlamlık. Ege Eğitim Dergisi, 11(2), 73-88.

Gürgan, U. (2006). Grupla psikolojik danışmanın üniversite öğrencilerinin yllmazlık düzeylerine etkisi. (Unpublished doctoral dissertation). Ankara University Institute of Social Sciences, Ankara.

Joseph, J. M. (1994). The resilient child: preparing today's youth for tomorrow's world. Cambridge: Perseus Publishing.

Karaırmak, Ö. and Siviş Çetinkaya, R. (2009). Benlik saygısının ve kontrol odağının psikolojik sağlamlık üzerine etkisi: Bir model test etme çalışması, in 18. National Education Sciences Council, (pp. 1-3).

Keleş, N. H. (2011). Pozitif psikolojik sermaye: tanımı, bileşenleri ve örgüt yönetimine etkileri. Organizasyon ve Yönetim Bilimleri Dergisi, 3(2), 345-350.

Kobasa, S. and Puccetti, M. C. (1983). Personality and social resources in stress resistance. Journal of Personality and Social Psychology, 45(4), 839-850.

Kobasa, S. C. (1979). Stressful life events, personality, and health: An inquiry into hardiness. Journal of Personality and Social Psychology, 37(1), 1-11. https://doi.org/10.1037/0022-3514.37.1.1

Kobasa, S. C., Maddi, S. R. and Kahn, S. (1982). Hardiness and health: A prospective study. Journal of Personality and Social Psychology, 42(1), 168-177. https://doi.org/10.1037/0022-3514.42.1.168

Koç, H. and Kızanlıklı, M. (2017). İş-aile ve aile-iş yaşamı çatıșması ile işgören performansı arasındaki ilişki: Otel işletmelerinde bir uygulama. Uluslararası İktisadi ve İdari Bilimler Dergisi, Özel Sayı 1, 114-130.

Li, M., Xu, J., He, Y. and Wu, Z. (2012). The analysis of the resilience of adults one year after the 2008 Wenchuan Earthquake. Journal of Community Psychology, 40(7), 860-870. https://doi.org/10.1002/jcop.21496

Luthans, F. and Youssef, C. M. (2004). Human, Social, and Now Positive Psychological Capital Management: Investing in people for competitive advantage. Organizational Dynamics, 33(2), 143-160. https://doi.org/10.1016/j.orgdyn.2004.01.003

Luthans, F., \& Youssef, C. M. (2007). Emerging positive organizational behavior. Journal of Management, 33(3), 321-349. https://doi.org/10.1177/0149206307300814

Luthans, F. Luthans, K. W. and Luthans, B. C. (2004). Positive psychological capital: Beyond human and social capital. Business Horizons, 47(1), 45-50. https://doi.org/10.1016/j.bushor.2003.11.007

Luthar, S. S. and Zigler, E. (1991). Vulnerability and competence: A review of research on resilience in childhood. American Journal of Orthopsychiatry, 61(1), 6-22. doi: 10.1037/h0079218.

Luthar, S. S., Cicchetti, D. and Becker, B. (2000). Research on resilience: Response to commentaries. Child Development, 71(3), 573-575. https://doi.org/10.1111/14678624.00168 
Luthar, S. S., Sawyer, J. A. and Brown, P. J. (2006). Conceptual issues in studies of resilience. Past, present and future research. Annals New York Academy of Sciences, 1094, 105115. doi: 10.1196/annals.1376.009.

Maddi, S. R., Khoshaba, D. M., Persico, M., Harvey, R. and Bleecker, F. (2002). The personality construct of hardiness. Journal of Research in Personality, 36(1), 72-85.

Malkoç, A. and Yalçın, İ. (2015). Relationships among resilience, social support, coping, and psychological well-being among university students. Turkish Psychological Counselling and Guidance Journal, 5(43), 35-43.

Misırlı, İ. (2002). Turizm sektöründe meslek standartları ve mesleki belgelendirme sistemi (Sertifikasyon). Anatolia Turizm Araştırmaları Dergisi, 13(1), 39-55.

Min, J. A., Yoon, S., Lee, C. U., Chae, J. H., Lee, C., Song, K. Y. and Kim, T. S. (2013). Psychological resilience contributes to low emotional distress in cancer patients. Support Care in Cancer, 21(9), 2469-2476. DOI: 10.1007/s00520-013-1807-6

Newman, R. (2002). The road to resilience. APA monitor on psychology, available at: http://www.apa.org/monitor/oct02/pp.aspx (accessed 22 June 2019).

Özcan B. (2005). Anne-babaları boşanmış ve anne-babaları birlikte olan lise ögrencilerinin yılmazlık özellikleri ve koruyucu faktörler açısından karşılaştırılması. (Yayınlanmamış Yüksek Lisans Tezi). Ankara Üniversitesi Eğitim Bilimleri Enstitüsü, Ankara.

Rhodewalt, F. and Zone, J. B. (1989). Appraisal of life change, depression and illness in hardy and nonhardy women. Journal of Personality and Social Psychology, 56(1), 81-88. DOI: $10.1037 / / 0022-3514.56 .1 .81$

Rossi, N. E., Bisconti, T. L. and Bergeman, C. S. (2007). The role of dispositional resilience in regaining life satisfaction after the loss of a spouse. Death studies, 31(10), 863-883. DOI: $10.1080 / 07481180701603246$

Rutter, M. (1990). Psychosocial resilience and protective mechanisms. In J. E. Rolf, A. S. Masten, D. Cicchetti, K. H. Nuechterlein, \& S. Weintraub (Eds.), Risk and protective factors in the development of psychopathology (pp. 181-214). (A shorter version of this chapter appeared in the "American Journal of Orthopsychiatry", 57 (1987): 316-31) Cambridge University Press. https://doi.org/10.1017/CBO9780511752872.013

Şahin, G. and Buzlu, B. (2017). Hemşirelik öğrencilerinde psikolojik sağlamlığın öz yeterlik sosyal destek ve etkili baş etme ile ilişkisinde algılanan stresin aracı rolü. Anadolu Hemşirelik ve Sağllk Bilimleri Dergisi, 20(2), 122-136.

Terzi, Ş. (2005). İyi olmaya ilişkin psikolojik dayanıklılık modeli. (Doktora Tezi). Access address

https://tez.yok.gov.tr/UlusalTezMerkezi/tezDetay.jsp?id=nSz1uDkiCxwDEPpkIfwVP w\&no=lyOdwbzEn0LLZBsZ0Gy9gA. Ankara (AAT 159406)

Terzi, Ş. (2008). Üniversite öğrencilerinde kendini toparlama gücünün içsel koruyucu faktörlerle ilişkisi. Hacettepe Üniversitesi Eğitim Fakültesi Dergisi, 35, 297-306.

Terzi, Ş. (2013). Üniversite öğrencilerinin psikolojik dayanıklılıkları ve algıladıkları sosyal destek arasındaki ilişki. Türk Psikolojik Danışma ve Rehberlik Dergisi, 3(29),1-11.

Voegler, M. E. (2000). Risk and protective factors associated with social resilience in homeless youth. (Unpublished Doctoral Dissertation). The University of North Coralina.

Yalım, D. (2007). Üniversite birinci sınıf ögrencilerinin uyumu: Psikolojik sağlamlık, başa çıkma, iyimserlik ve cinsiyetin rolü. (Unpublished Master Thesis). Middle East Technical University Institute of Social Sciences, Ankara. 
Yıldırım, P. K., Yıldırım, E., Otrar, M. and Şirin, A. (2015). Ergenlerde psikolojik dayanıklılık ile benlik kurgusu arasındaki ilişkinin incelenmesi. Marmara Üniversitesi Atatürk Eğitim Fakültesi Eğitim Bilimleri Dergisi, 42, 277-297.

Yılmaz, H. and Sipahioğlu, Ö. (2012). Farklı risk gruplarındaki ergenlerin psikolojik sağlamlıklarının incelenmesi. İlköğretim Online, 11(4), 927-944.

Zautra, A., Hall, J. and Murray, K. (2010). Resilience: A new definition of health for people and communities. In Hall, J S, Reich, J W, \& Zautra, A J (Eds.) Handbook of adult resilience. Guilford Press, United States of America, pp. 3-30.

Prayag, G., Spector, S., Orchiston, C. and Chowdhury, M. (2020). Psychological resilience, organizational resilience and life satisfaction in tourism firms: Insights from the Canterbury earthquakes. Current Issues in Tourism, 23(10), 1216-1233. https://doi.org/10.1080/13683500.2019.1607832 